\title{
Impact of Land Use Change Study on Reservoir's Sediment Yield using SWAT Model Platform
}

\author{
Girma Kebebew Tufa, Bogale G Mariam
}

\begin{abstract}
The overall goal of this study is to evaluate the effect of land use on reservoir's sediment yield by applying Arc SWAT model interface with GIS and identify the vulnerable sub basin in Neshi dam watershed. Different input data were collected from different sources including Ministry of Water, Irrigation and Energy, and Ethiopia National Meteorological Agency. The study was done using historical records of nineteen years for Neshi Watershed. The calibrated flow and sediment for the 1992-2001 years gave $R^{2} 0.77,0.92$ and NES $0.64,0.96$, respectively. The validated flow and sediment for the 2002-2008 years gave $R^{2}$ $0.72,0.93$ and NES $0.75,0.95$, respectively.In this study the SWAT model yields average annual sediment load of 634.49, 516.82 and 542.56 ton/ha/yr for land use change of 1990, 2010 and 2017, respectively at Neshi outlet dam site. Therefore, the issue of land use change impact on sediment yield on reservoir as part of the integrated adaptation mitigation measures program in order to achieve sustainable development is very relevant. The output of this study can help planners, decision makers and other stakeholders to plan and implement appropriate soil and water conservation strategies.
\end{abstract}

Key words: Sediment yield, SWAT Model, Neshi Watershed, LUC, SWAT CUP

\section{INTRODUCTION}

Assessment and analysis of soil erosion, sediment yield and their intake and deposition in reservoir is essential. Although (Taye, H. 2016) has considered dynamics of Land Use and Cover Changes (LUCC) with SWAT model that are related to land use change in the sub basin on stream flow, he has not considered about sedimentation effect under land use/cover changes for Amerti-Neshi reservoir

\section{A. Statement of the problem}

The absence of Land use planning in Fincha Amerti-Neshi watershed may have resulted in erosion problems due to population density and changing forests into agricultural land.

\section{B. Scope of the Study}

The scope of this study is to determine reservoir sediment yield at the U/stream and watershed of the reservoir to recommend appropriate mitigation measure for storage loss of Neshi reservoir.

\section{STUDY DETAILS}

\section{A. Objective of the Study}

The overall objective of this study is to evaluate the impact of land use changes on Neshi reservoir's sediment yield, by using Arc SWAT model. The specific objectives are:

* To estimate the specific sediment yield at Neshi reservoir by SWAT model

* To evaluate the impact of land use change on average annual sediment yield.

* To identify the vulnerable sub basin to yields of high erosion process.

\section{B. Description of the study Area}

Geographically Neshi reservoir is located in Oromia region, Horro Guduru Wollega Zone, Abbay Choman Woreda in the Blue Nile River Basin having a drainage area about $230 \mathrm{~km}^{2}$.The area is bounded by escarpments from east, west and north within the general boundaries of latitudes $9^{\circ} 40^{\prime} \mathrm{N}$ to $9^{\circ} 50^{\prime} \mathrm{N}$ and longitudes $37^{\circ} 0^{\prime}$ to $37^{\circ} 20^{\prime} \mathrm{E}$ at an altitude between $2,588 \mathrm{~m}$ and 2,202 $\mathrm{m}$ above sea level at about $312 \mathrm{~km}$ north-west of Addis Ababa (Bayissa, 2007)

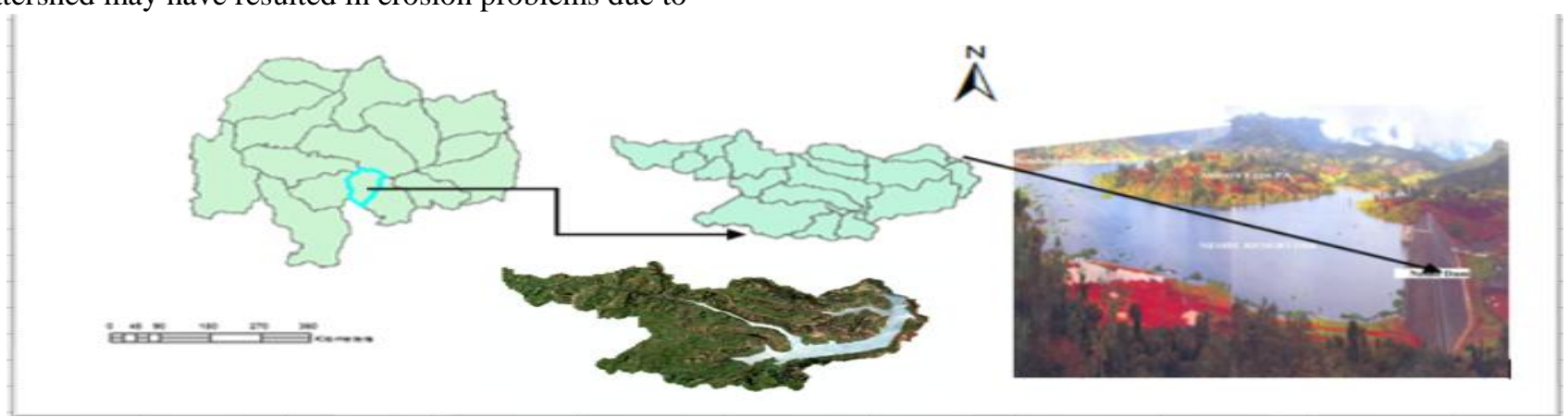

Figure 1. Location of Neshi Reservoir

Revised Manuscript Received on September 25, 2020.

* Correspondence Author

Girma Kebebew Tufa*, MSc, Lecturer, Hydraulic and Water Resources Engineering Department, Wollega University, Ethiopia (girmakebebew92@gmail.com)

Bogale G Mariam, Assistance professor, Faculty of Hydraulic and Water Resources Engineering, Arba Minch University, Ethiopia (bgmariam@gmail.com)

(C) The Authors. Published by Blue Eyes Intelligence Engineering and Sciences Publication (BEIESP). This is an open access article under the CC BY-NC-ND license (http://creativecommons.org/licenses/by-nc-nd/4.0/)

\section{METHODOLOGY OF STUDY}

SWAT requires daily meteorological data that could either read from a measured data set or different sources to generate by SWAT model. In this research the weather data (climate, relative humidity, temperature, rainfall, solar radiation)

\section{Published By:}




\section{Impact of Land Use Change Study on Reservoir's Sediment Yield using SWAT Model Platform}

variables were used from the period of 1990 to 2017 for 28 years data. These data were obtained from Ethiopian National Meteorological Agency (NMA) for stations located within and around the catchment. Some of the meteorological stations have no full dataFirst class station or synoptic was the station that has all relevant data, second categories station was the station that has many missed data in their content and the third class stations were the stations that has only rainfall and temperature (maximum and minimum) data. Among five stations Shambu station was the first class station and used for weather generated to SWAT model and the rest of the stations was the third class station.One of the meteorological stations (Neshi) found inside the catchment. The other meteorological stations, which were found outside the catchment, are Shambu, Fincha, Alibo and Homi.

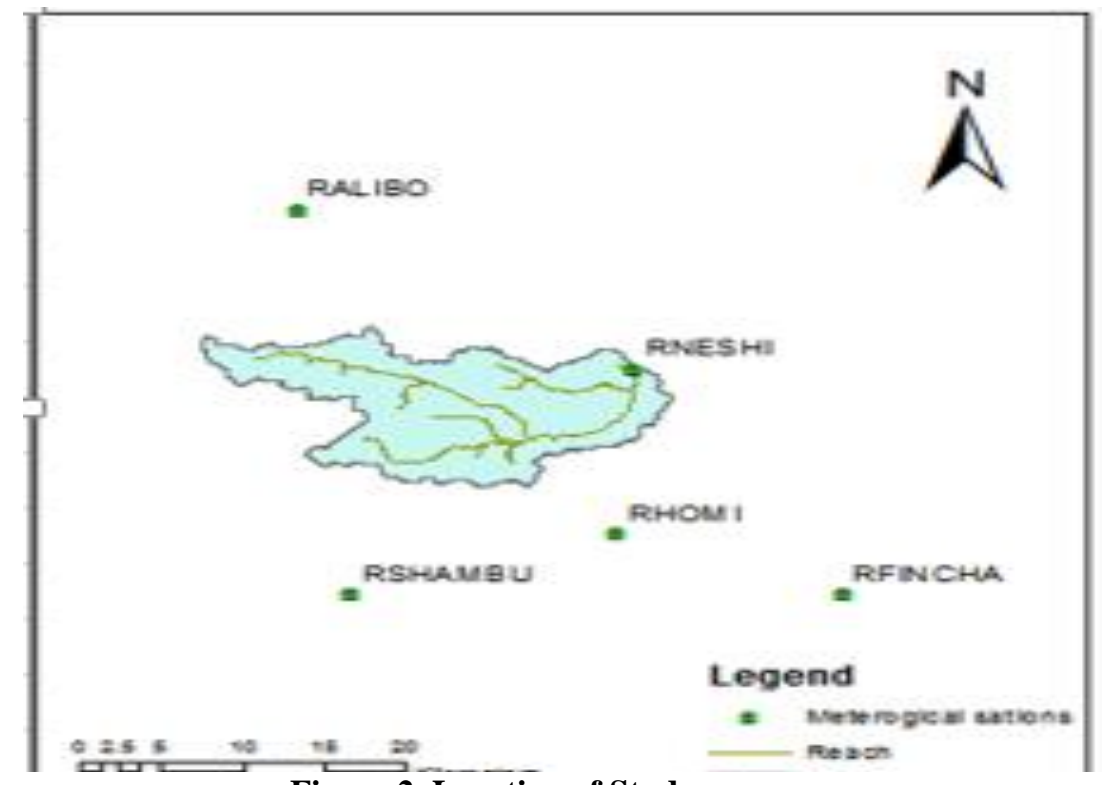

Figure 2. Location of Study area

\section{A. Data Requirement}

\section{Data Collection for SWAT Input}

Soil and Water Assessment Tool required the following data to be defined for the physicalwatershed representation, topography data (Digital Elevation Model), climate (dailymeasured and monthly statistical weather data), flow data, soil and land use data (maps andphysical parameters

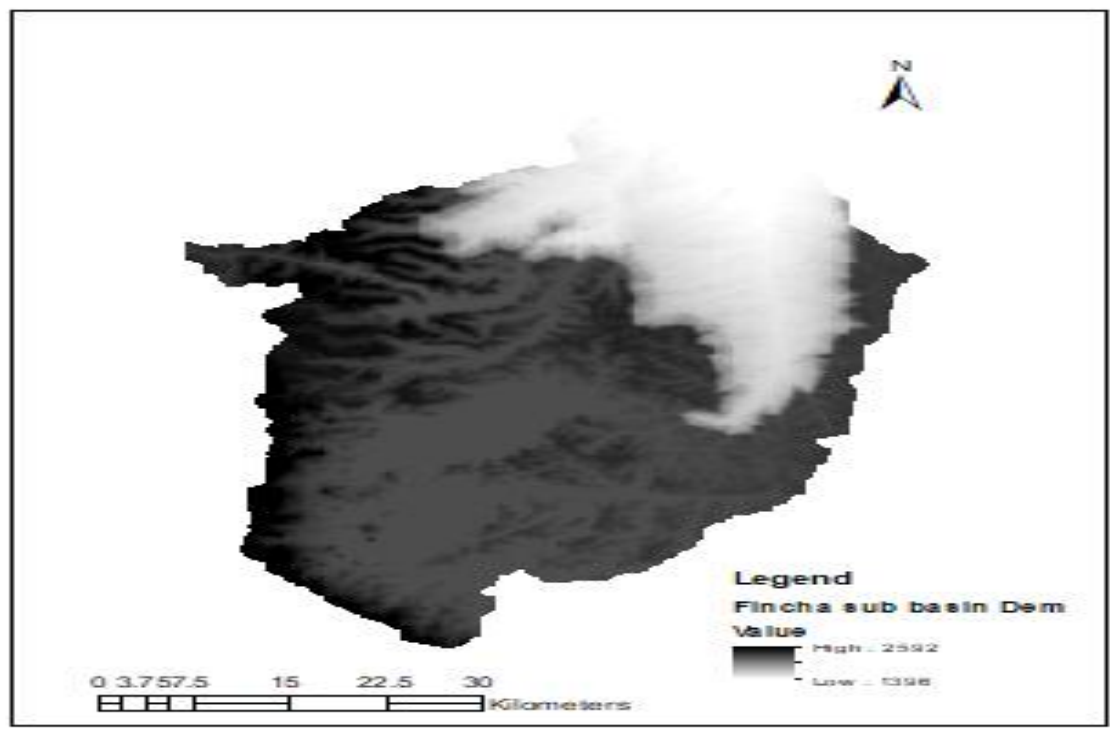

Figure 3. DEM (30) of Fincha basin

\section{Land Use Land Cover}

The land use map of Fincha sub basin clipped and dissolved into Neshi watershed then,the clipped land use map was used for SWAT land use reclassification.

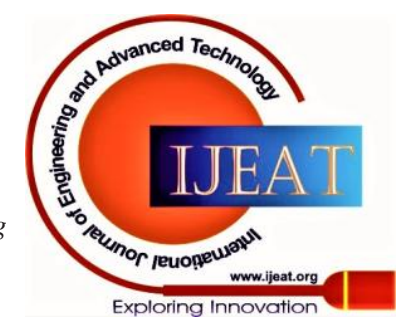



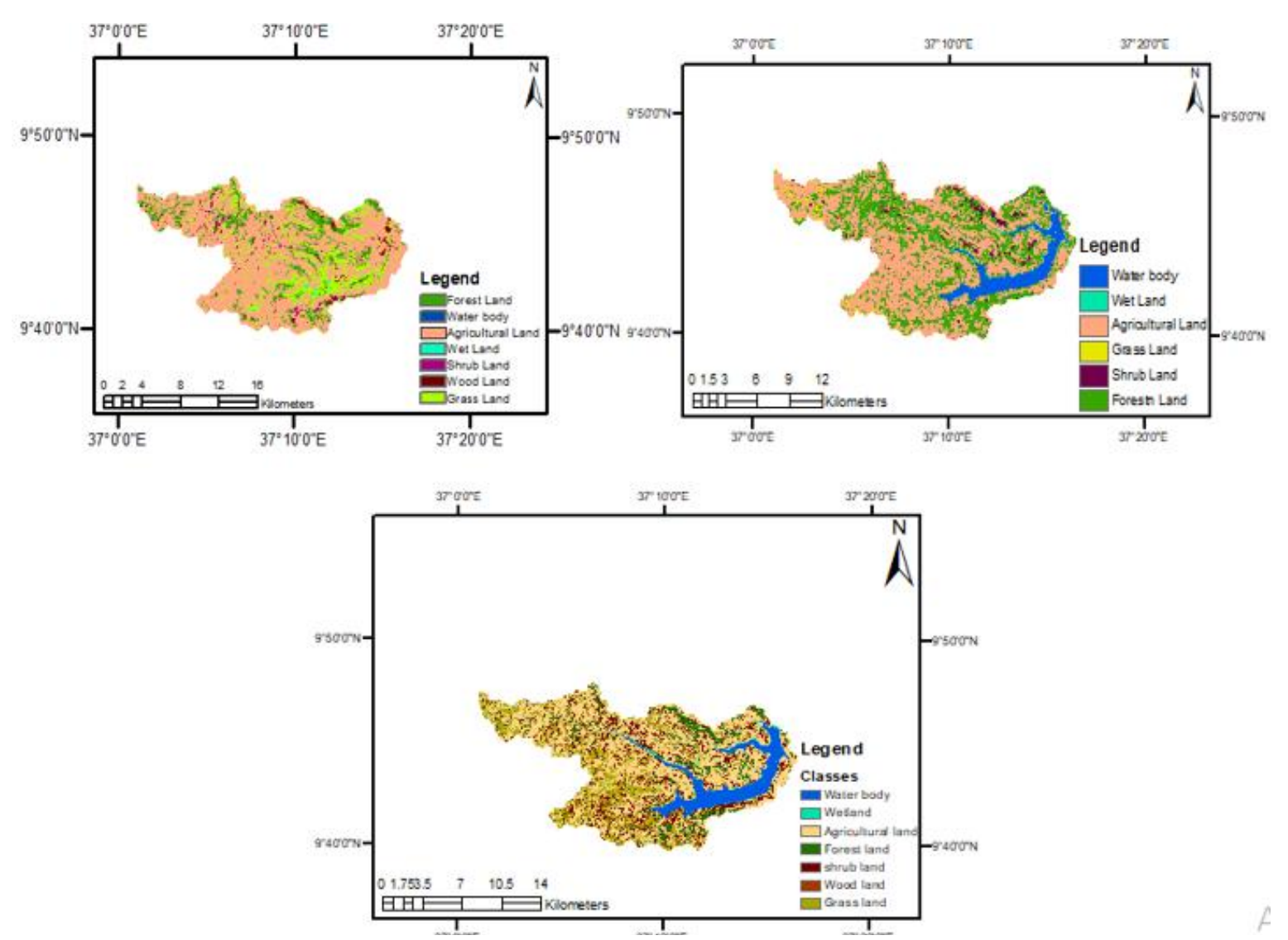

Figure 4. LUC for Neshi watershed at 1990, 2010 and 2017 respectively.

3. Temperature The daily data of maximum temperature and minimum temperature were measured in different station near to the Neshi reservoir

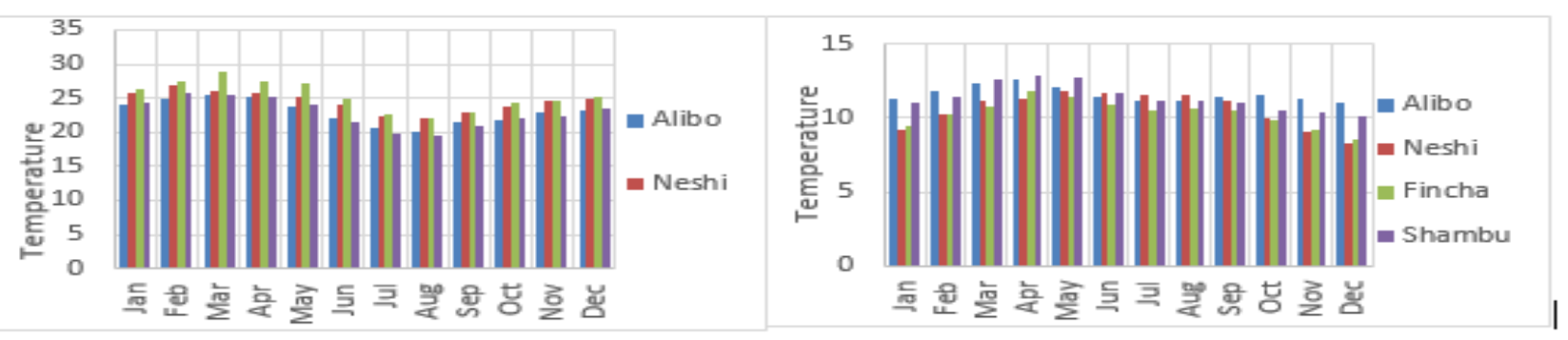

Figure 5.Average of Max and Min To respectively

\section{B. Hydrological Data}

Observed flow data was required for the Soil and Water Assessment Tool (SWAT) calibration and validation. The observed stream flow data is available from 1990-2008.

The stream flow data from 1990-2001 was used for model calibration and from 2002-2008 flow data was used for model validation.

\section{Filling of Missed Data}

There were different methods of filling the meteorological and hydrological data. In this paper the arithmetic mean method was used when the annual data values at each of the neighboring gauging differ was less than $10 \%$ from that for the gauge with missed data and normal ratio methods were used when the annual data values at each of the neighboring gauging stations different was greater than $10 \%$ from that for the gauge with missed data.

\section{Consistency of Weather Data}

Data consistency was the ways of checking the uncertainty of meteorological data that was taken during gauging or measuring of hydro metrological data

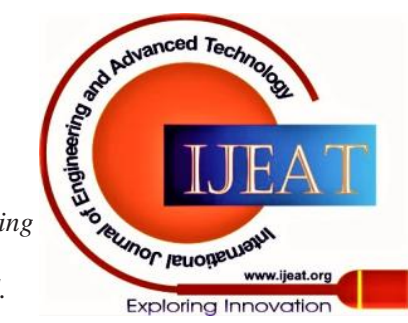


Impact of Land Use Change Study on Reservoir's Sediment Yield using SWAT Model Platform

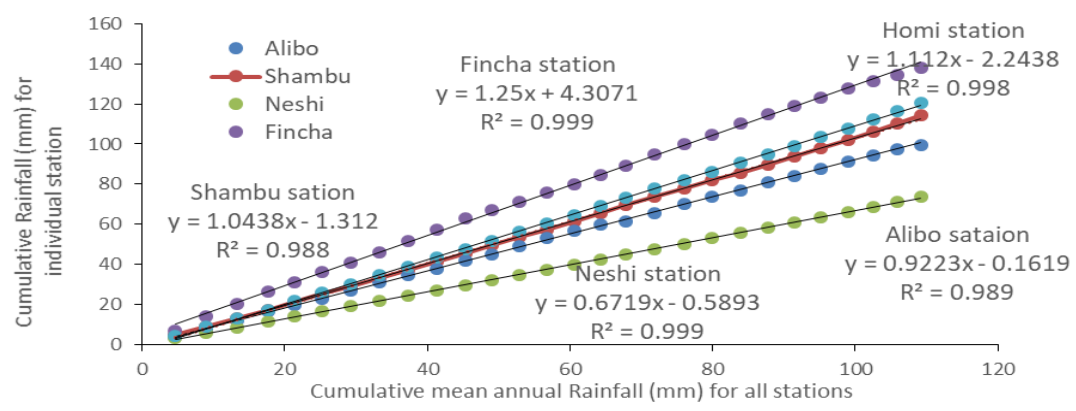

Figure 6.Double Mass Curve Preparation

\section{E. Sediment Rating Curve Preparation}

A sediment rating curve is a relation between the sediment and river discharges. Such a relationship is usually established by regression analysis, and the curves are generally expressed in the form of a power-law type equation.
$C S=a * Q b$ 4.1

Where Cs is suspended sediment concentration (kg/se); Q is water discharge $\left(\mathrm{m}^{3} / \mathrm{s}\right)$; a $\& \mathrm{~b}$ are regression coefficient and exponent, respectively.

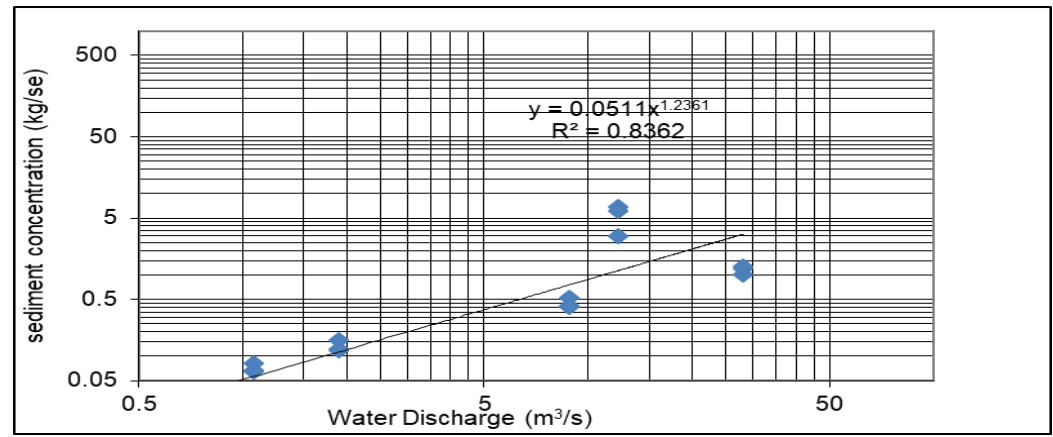

Figure 7.Sediment Preparation Curve

IV.

RESULTS AND DISCUSSIONS

\section{A. Model Calibration and Validation}

\section{Model Calibration for Flow}

The stream flow comparison has been done between the observed and simulated discharge values for 10 years' timeyears of flow data during 1990-1991 was taken as warming steps during 1992 - 2001 on the daily basis. Initially two time.

Table 1. Fitted value for parameter sensitive to flow

\begin{tabular}{llll}
\hline Parameter Name & Fitted Value & Min_value & Max_value \\
\hline 1:V_CN2.mgt & 95.17 & 70 & 98 \\
2:V__ALPHA_BF.gw & 0.0684 & -0.2 & 0.2 \\
3:V_GW_DELAY.gw & 211.01 & 30 & 450 \\
4:V_GWQMN.gw & 1.502 & 0 & 2 \\
5:V_CH_N2.rte & 0.0681 & 0 & 0.3 \\
6:R_SOL_AWC (...) & 0.3178 & -0.2 & 0.4 \\
7:R_SOL_K (...).s & 2.2605 & 1.5 & 6 \\
8:V_HRU_SLP.hru & 0.749 & 0.74 & 0.91 \\
9:V_SURLAG.bsn & 8.751 & 1 & 24 \\
10:V_BIOMIX.mgt & 0.1438 & 0.1 & 0.3 \\
11:V_ESCO.bsn & 0.9958 & 0.8 & 1 \\
12:V_EPCO.bsn & 0.515 & 0 & 1 \\
\hline
\end{tabular}




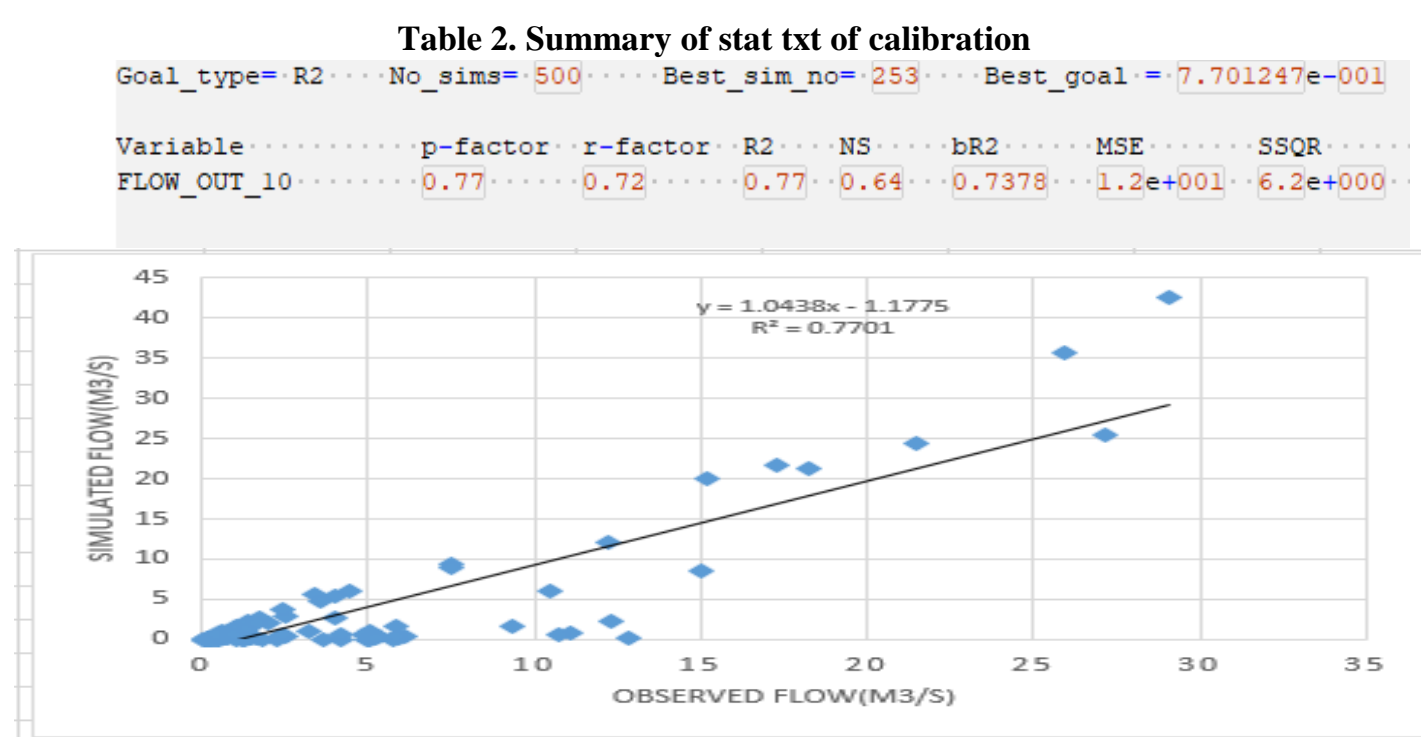

Figure 8.Scattered plot flow of Neshi station during Calibration

The result of model calibration was the best for evaluating a model performance. That means the statical analyses of model after calibration by using regression coefficient or $\mathrm{R}^{2}$ shows that a best relation of the stream flow data was 0.83 and the NSE shows 0.64 and this value shows the model was of good performance during the calibration.

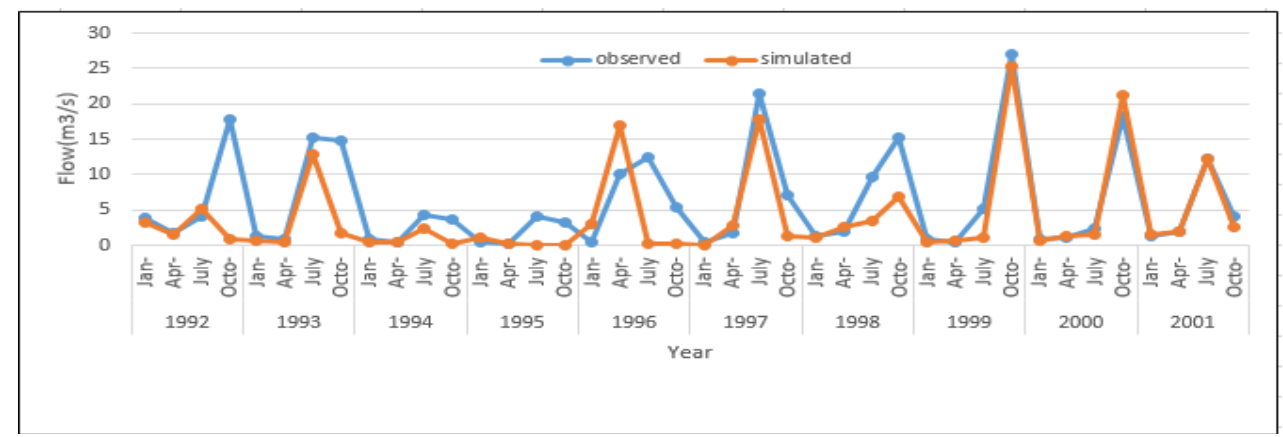

Figure 9. Comparison of Observed and Simulated monthly flow

Table 3.Calibration statistics of average monthly simulated and gauged flow

\begin{tabular}{|c|c|c|c|c|c|}
\hline \multirow[t]{2}{*}{ Period } & \multicolumn{2}{|c|}{ Average flow $\left(\mathrm{m}^{3} / \mathrm{s}\right)$} & \multirow[t]{2}{*}{$\mathrm{D}(\%)$} & \multirow[t]{2}{*}{$\mathrm{R}^{2}$} & \multirow[t]{2}{*}{ NSE } \\
\hline & Gauged & Simulated & & & \\
\hline 1992-2001 & 240.428 & 158.516 & -34.06 & 0.77 & 0.64 \\
\hline
\end{tabular}

\section{Flow Validation}

It involves re-running the independent of data used in from a period 2002 to2008 at Neshi gauging station were calibration (e.g. differing time period), but keeping the used to validate the model for a monthly time-period. calibrated parameters unchanged. In this case, flow data

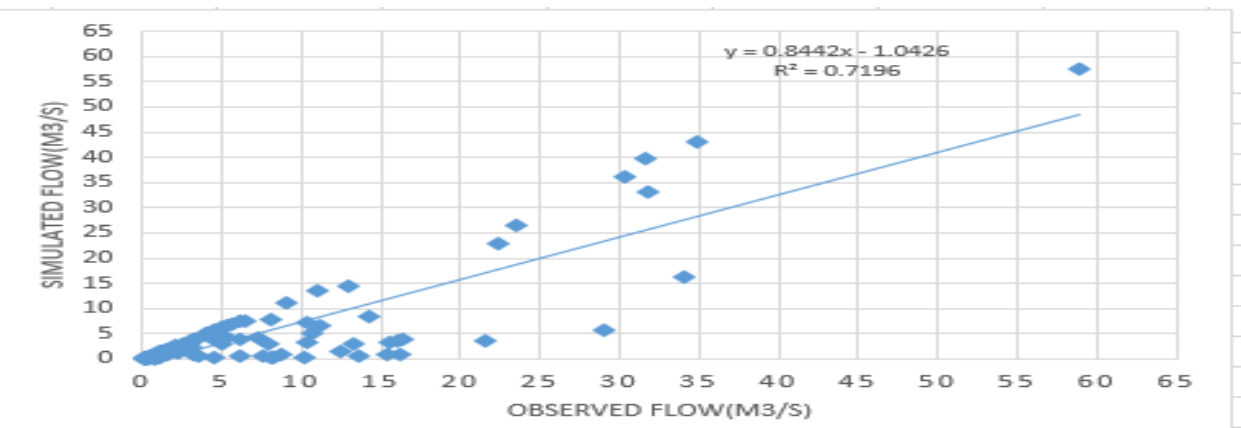

Figure 10. Neshi station flow Validation Scattered plot 


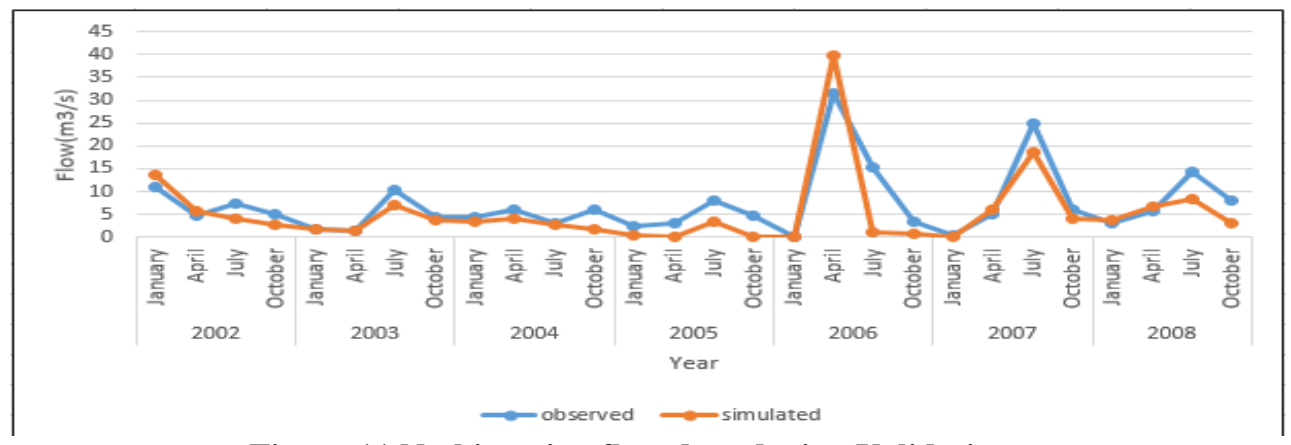

Figure 11.Neshi station flow data during Validation

The goodness-of-fit measures the coefficient of correlation $\left(\mathrm{R}^{2}=0.72\right)$, the Nash-Sutcliffe simulation

efficiency $(\mathrm{NSE}=0.75)$ and the percent difference $(\mathrm{D}=-$ 26.11\%).

Table 4. Validation statistics of average monthly simulated and gauged flow

\begin{tabular}{llllll}
\hline Period & \multicolumn{2}{l}{ Average flow $\left(\mathrm{m}^{3} / \mathrm{s}\right)$} & $\mathrm{D}(\%)$ & $\mathrm{R}^{2}$ & NSE \\
\cline { 2 - 3 } & Gauged & Simulated & & & \\
\hline $2002-2008$ & 201.8184 & 149.1344 & -26.11 & 0.72 & 0.75
\end{tabular}

\section{B.Sediment Yield determination under Land Use Changes}

It is also valuable to know the monthly value of land use land cover changes on hydrological process under the same wet and dry season for the 1990, 2010 and 2017 study periods.
This is essential mostly for decision makers, hydrologists, water resources planners, flood protection, agriculturists and the community at large to know the seasonal variation of the hydrological process. As it provides information on the occurrence of minimum and maximum value of the event.

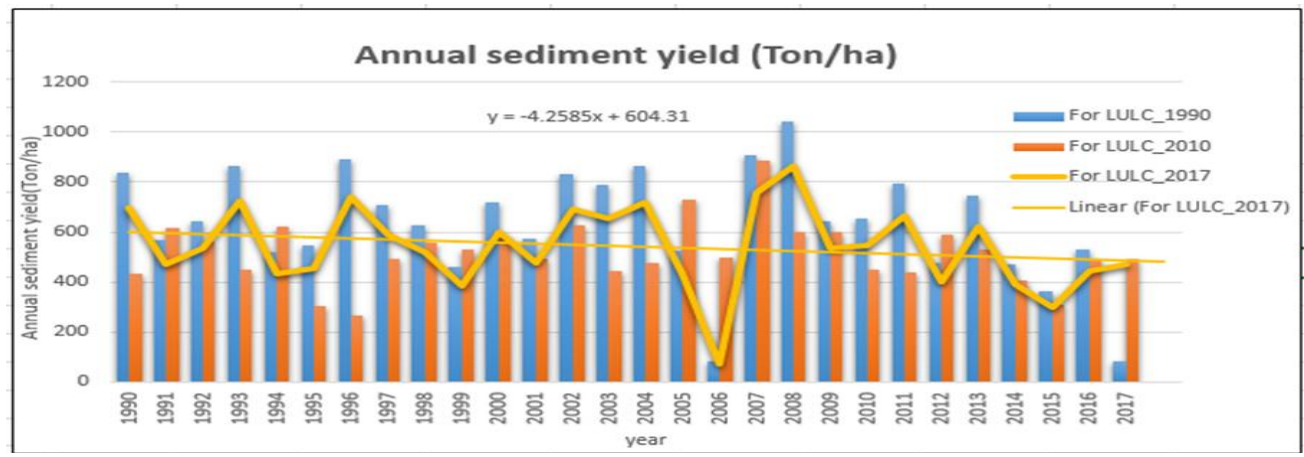

Figure 12. Annual sediment yield under 1990, 2010 and 2017 Land Use Change

The specific sediment yield based on simulated sediment load by SWAT model for 1990, 2010 and 2017 Land Use Cover from Neshi watershed of area $230 \mathrm{~km}^{2}$ was 77.24 tons $/ \mathrm{km}^{2}, 62.92$ tons $/ \mathrm{km}^{2}$

66.05 tons $/ \mathrm{km}^{2}$ respectively.

Hence, these facts show us how much the Neshi reservoir is threatened by sediment inflow from the watershed unless proper measure is taken.

\section{C.Land Use Change Scenario Analysis}

The LUC change scenario was developed for the change detection analysis to understand and quantify the trend of the land use land cover change from 1990 to 2010, from 2010 to 2017 and from 1990 to 2017 which obtained from Ethiopia Mapping Agency.

Table 5. Land Use Cover Change class

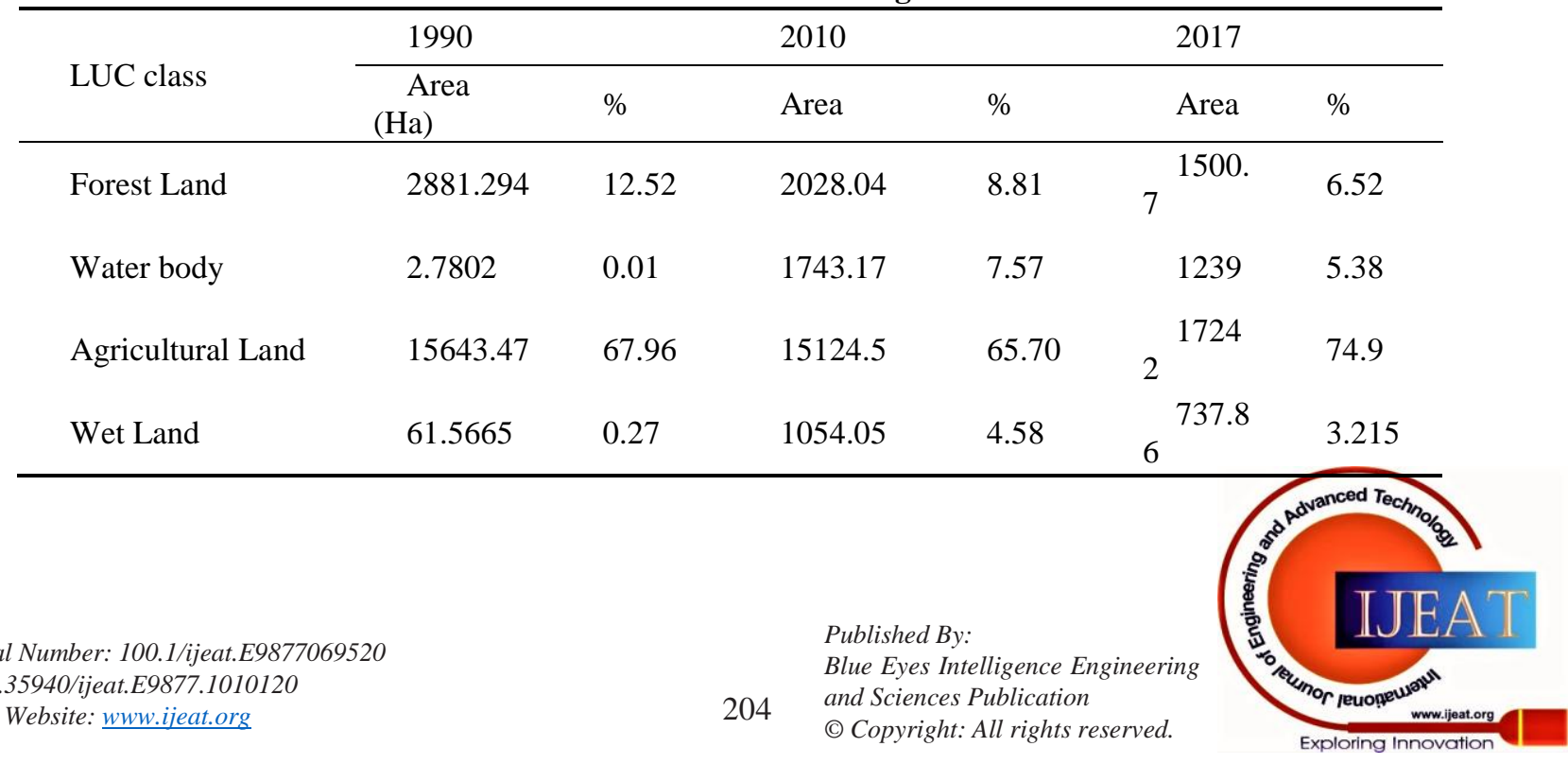




\begin{tabular}{lllllll}
\hline Shrub Land & 244.64 & 1.06 & 154.65 & 0.67 & 960.4 & 2.445 \\
Grass Land & 3576.62 & 15.57 & 2311.31 & 10.04 & 1720 & 7.44 \\
Wood Land & 609.6344 & 2.65 & 604.17 & 2.62 & 27.27 & 0.12 \\
Total & 23000 & 100 & 23000 & 100 & 2300 & 100 \\
\hline \multicolumn{7}{c}{ Table6. Land Use and Land Cover Change distribution at Neshi watershed } \\
\hline LUC Class & $1990-2010$ (\%) & $1990-2017$ (\%) & $2010-2017$ (\%) & \\
\hline Forest Land & -3.7065 & -5.9971 & -2.2906 & \\
Water body & +7.5603 & +5.3702 & -2.1901 & & \\
Agricultural Land & -2.2541 & +6.9419 & +9.1960 & & \\
Wet Land & +4.3114 & +2.9378 & -1.3735 & & \\
Shrub Land & -0.3909 & +1.3720 & +1.7629 & & \\
Grass Land & -5.4964 & -8.0951 & -2.5986 & & \\
Wood Land & -0.0237 & -2.5298 & -2.5060 & \\
\hline
\end{tabular}

The result over 1990 to 2010 has indicated that only water body and wet land increased This shows the creation of Neshi Dam at 2010 demand for land has increased resulting into conversion of the land areas to water body. The result from 1990 to 2017 also shows an increase in agricultural land, water body and range lands where as forest land and grass land has get declined.

\section{CONCLUSION}

The study result showed that the specific sediment yield based on simulated sediment load by SWAT model for 1990, 2010 and 2017 LUC from Neshi watershed of area $230 \quad \mathrm{~km}^{2}$ is $\quad 77.24, \quad 62.92$ and 66.05 tons $/ \mathrm{km}^{2}$ respectively. In the same manner, the average annual simulated sediment load from watershed for 28 years was estimated using the SWAT model for 1990, 2010 and 2017 LUC was 634.49, 516.815 and 542.56 tons/yr. respectively. In terms of sediment yield, sub basin 5 contributes a maximum load whereas sub basin 10 contributes a minimum sediment load for the study periods. The output of this study can help planners, decision makers and other stake holders to plan and implement appropriate soil and water conservation strategies.

\section{FUTURE SCOPE}

To manage this problem effect of land use changes on reservoir sedimentation was considered in this thesis so as to contribute something in problem solving in this area.

It is better to hold additional near meterogical station to Neshi station that can have made accurate estimation of the missing data rather than the furthest one. More Watershed intervention or management activities especially on Subbasin 2, 8, 11, 15 and 16 should have to be designed to reduce sediment yield from the watershed.

\section{CONFLICT OF INTEREST STATEMENT}

On behalf of all the authors, the corresponding author states that there is no conflict of interest.

\section{REFERENCES}

1. Awulachew.S.,McCartney,Steen huis, $T$ and Ahmed .A (2008). Review of hydrology, sediment and water resource use in the Blue Nile Basin. pp87-pp95.

2. Bayissa, C. (2007). Assessment of Malaria as a Public Health Problem in Finchaa Sugar Factory based on Clinical Records and Parasitological Surveys. MSc Thesis. Addis Ababa University,Ethiopia.: unpublished.

3. Bezuayehu, T. (2006). people and Dams: Environmental and socieconomic impacts of Fincha'a hydropower dam, western Ethiopia. Tropical Res. Manag.Paper, 75.

4. Easton.K.,Fuka,D.,White,D.,Collick,A.and Biruk Ashagre (2010). A multi basin SWAT model analysis of runoff and sedimentation in the Blue Nile, Ethiopia. Hydrology and Earth System Sciences, 14(10), 1827-1841.

5. Friedrich ,K.,Kochi Ann Van Griensven,K.,Sirak Tekleab and Teferi,E. (2012). The Effects of Land use Change on Hydrological Responses in the Choke Mountain Range (Ethiopia). Helmholtz Centre for Environmental Research.

6. Gassman, R.,Reyes,M.,Green,CH.and Arnold,G. (2007). The Soil and Water Assessment Tool: Historical Development. Applications, and Future Research Directions. Transactions of the ASABE.

7. Gizaw , L.,Haddis,A., Deboch,D.and Birke,W. (2004). Assessment of factors contributing to eutrophication of Abasamuel water reservoir in Addis Ababa Ethiopia. Journal of Health Science, 112-113.

8. Habtamu, B. (2017). Simulating Hydrological and ClimateVariabilityImpacts on the Watershed of Legedadi Reservoir using ArcSWAT. Addis Ababa: Unpublished.

9. ICOLD. (2009). Sedimentation and sustainable use of reservoirs and river systems. paris.

10. Mekonnen ,A.,Andres,W,,Bijan.D.and Admasu ,G. (2009) Hydrological modelling of Ethiopian catchments using limited data. Hydrol. Process, 23, 3401-3408.

11. Neitsch, J.,Arnold,J., Kirniy,J. and William, J. (2005). Soil and Water Assessment Tool, Theoretical documentation. Texas A \& M Black land Research Centre.

12. Setegn,S., Srinivasan,R., Daegahi,B. and Meiesse ,A.(2008). Spatial delineation of soil erosion vulnerability in the lake Tana Basin, Ethiopia. Hydrological Processes.

13. Taye, H. (2016). The Dynamics of Land use Land cover change on the Stream Flow in Fincha Amerti Neshe Sub-basin: Abay basin, Ethiopia. Addis Ababa, Ethiopia: Unpublished.

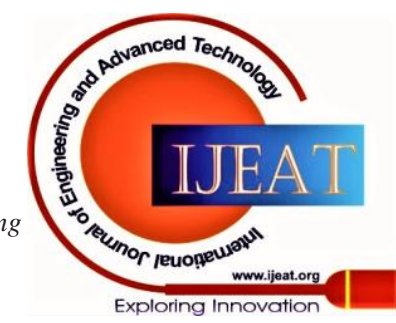


Impact of Land Use Change Study on Reservoir's Sediment Yield using SWAT Model Platform

\section{AUTHORS PROFILE}

Girma Kebebew is currently working as a lecturer Hydraulic and Water Resources Engineering Department, Wollega University, Ethiopia. He received his MSc in Sustainable Water Resources Engineering from Arba Minch University. His research area is modelling reservoir sedimentation. (girmakebebew92@gmail.com)

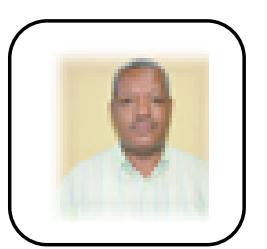

Bogale GebreMariam is currently working as Assistant Professor in the Faculty of Hydraulic and Water Resources Engineering, Arba Minch University, Ethiopia. He received his $\mathrm{PhD}$ degree in Lake Hydrodynamics from Freie University of Berlin, Germany, and his MSc degree in Hydraulics (Hydro informatics) from IHE, Delft, The Netherlands. His research area is streamflow, erosion and sediment transport modelling.

(bgmariam@gmail.com) 